http://doi.org/10.31861/pytlit2020.101.177

УДК 81'373.612.2:78(474)

\title{
METAPHOR IN THE CONTEXT OF BALTIC MUSIC: THE IDEA OF ETERNAL RETURN
}

\author{
Jūratè Landsbergytë-Becher \\ orcid.org/0000-0003-2356-7264 \\ jurate128@yahoo.de \\ Lithuanian Culture Research Institute \\ Saltoniškiu g. 58, 08105, Vilnius, Lithuania
}

\begin{abstract}
Metaphor is the essential form for building momentum in the phenomenon of Baltic music. It created a new silent style of defensiveness and transcendentality, which eventually could help to change the self-awareness of the nation. The purpose of this article is to research the linguistic power of a metaphor, its transfer into the music and how it helped to uncover disinformation in the period of Soviet ideological domination. The comparative methodology is used to examine metaphors in the areas of music, literature, political science, and aesthetics of art philosophy. This article is structured to show the motion of metaphor in particular turns of time. Metaphor is a powerful instrument to raise the dimensions of the archetypes of national identity and statehood rights. Its usage could be compared with religion, nature, sacrality of space and history, and it is necessary for the change in the knowledge about the nation's development. Metaphor is the renewed road to comprehend the importance of statehood existence and what happened in Baltic states during the times of crucial changes. It could be said that the metaphor helped to regain independence without the army and spreads its influence similarly at the present day, penetrating the new media streams connecting the matters of statehood. The article findings summarise the origins of the power of the nation based on the phenomenon of the resurrection of archetypes (under the theory of C. G. Jung), which were rediscovered by using principles of psychology.

Keywords: Baltic, metaphor, history, space, rhythm, waves.
\end{abstract}

(C) Ландсбергіте-Бехер Ю., 2020 


\section{Metaphor: Linguistic power of a Sign of Passing Time Versus Disinformation.}

The significance of metaphors in the culture of thought of the Baltic countries has grown tremendously due to historical fractures caused by extraordinary circumstances. Literature, as well as visual art and music, have become the powerful action field for metaphors confronting the deformation of damaged historical time - disinformation and ideological psycho-terror of the image of distorted identity. The metaphor could bypass everything, jump over, deny in its nameless levels, and create a new experience of history, the worldview, and a sense of exigency for truth. It could happen only indirectly, figuratively. Such potentiality has been enabled by the lightness of linguistic play, reflexivity, and other aspects of the rhetorical soft power, which allow absorbing the reality without affecting its original levels of archaic causes, leaving them in a field of foreseeability. This feature preserves the truth dimension and ability to discern things from a distance, prevents from the direct collision with the antagonistic system; however, it seems discriminated, stripped of the meaning. Nevertheless, the word, like an arrow, spurts upward in the form of a sign and reaches its goal signalling, touching the core of truthfulness, awakening the meaning blocked in a distinct distortion zone. The return of the selfhood of soul and culture was and still is very important for the Baltic countries, which suffered the aftermath of the Russian occupation filled with deformations of historical time, and sought for metaphors to avoid the consequences of being besieged from the truth. Consequently, the best instrument here was the discovery of metaphorical language, which penetrated all fields of culture and the humanities - literature, music, visual art and cinematography, and even their research areas. The metaphor has become a paradigm of thought, which connects the wholeness of statehood, its contexts, and exploration. Here, the metaphor has also embraced a cultural mission - the resurrection of nations from the darkness, intentionally entering the archaic layers, connecting them with the present and fragmented unique historical contexts of the fractured time. The metaphor was a powerful instrument during Soviet times. Thus, the metaphor streaming from under a light writer's pen, like the melody of a song or "the will of the world", stirs up the blocked land of suppressed national archetypes, buried in pain and saturated with lies, 
poisoned and frozen, resurrecting these symbols for the unconventional confrontation with history and its revival. The most important here is to transform its music - the context into a sign and wholeness (Stonyte 2014).

\section{Archetype and metaphor: an instrumental fusion in music providing the immunity of the other space or sacrality.}

In the expression of Baltic selfhood, the metaphor embodies a transfer of meanings from one level to another. Metaphor, according to the international dictionary, is a comparison based on the juxtaposition of phenomena, not related but having similar characteristics, which are a very significant gesture of restoration and a dramaturgical factor determining the labelling, impetus and connections of archetypes. Here, the area of action of metaphors begins - the dramaturgy of the archetype of the Self, unleashing the expression and vivacity of its identity, influencing the processes of transformation of archetypes. In particular, the role of metaphor in Baltic phenomenalism is fundamental, paradigmatic, opening the mission of the archaeology of memory, acting as an interdisciplinary aspect of art psychology, history, politics and geopolitics.

In this context, the theory of archetypes is interpreted according to the problems set in the works of Carl Gustav Jung (1875-1961) (Jung 2013: p. 496). The guiding processes and Shadow - Ego - Self axis are the factors characterised by dramaturgical processuality and regularity. The essential equivalent - the Self - the archetype of archetypes is close to the Balticism through the dramaturgical process and connected to the depth and the phases of its processes, of which the last one to some extent is equated to the religious experience - the Enlightenment. Thus, the Jungian theory of archetypes and the dramaturgy of the Self are usually awakened by a metaphorical gesture. Its intonational cell, a repetitive movement, and minimalism allow the unlocking of the essential paradigms of Balticism. Such metaphoric language could be compared with a sacred canon where the idea of eternal return arises revealing the return of the Baltic selfhood and contains several essential elements: cycles, repetitions of movements, ritualistic monotony of rhythms as an eternal return of intonational cell. 


\section{The first metaphor of Baltic music: "the cry from the depth".}

Everything starts from the contact of the archetype of the Self with darkness. Here, the images of the hum of the earth, chaos, darkness and the dense low-sounding Bourdon bass flow. As they evolve, the essential impulses for change - the syncopated rhythm, the steps of a passacaglia, the laments, the motif of "the cry from the depths" appear. The motif has been already awakened by a gesture of metaphor, whether with literary or historical documentary context, and it continues to form exclusive meanings of its symbolic signs, which guide the entire process of thought. First of all, the intonational cell, the repetitive movement, and the minimalism inspire to create a system of dramaturgical action that allows us to unravel the fundamental paradigms of Balticness like the sea waves or the pulse of an alive heart. Semiotic analogues become feasible here: mythemes of C. Levy-Strauss, isotopies of J. Greimas ${ }^{1}$, equivalents of intonational cells and structural components of another system of the wholeness (as in Bronius Kutavičius oratorio "Last Pagan Rites", 1978, Arvo Pärt "Fratres", 1976).

Here, the first metaphor - the archaic image appears following the words of a psalm (or chorale): "Domine, Clamavi Ad Te" (Lord, I Cry to You / Aus Tiefer Not Schrei Ich Zu Dir) with the motion and awakening motif - the cry to get up and move from darkness to light. In that way, the musical metaphor begins the act of transferring hum from the formless and transformational levels, captured by the emerging lines of melody fragments. Such style is like a curse, a circle and the rising vertical, which pierces it through, also becomes an act of motion of musical textures, scenography and notation graphics embedded with geometric dimensions (Bronius Kutavičius oratorio cycle "Last Pagan Rite", 1978, "From The Yotvingian Stone", 1981, "The Tree of the World", 1986, "Magic Circle of Sanskrit", 1993). What matters here it is the intersection of significance. Convergence brings the levels closer together, intensifying the action of the metaphor not only by moving the image from one height to another but also by piercing one level with another. It is illustrated in both oratorios by the singer's stand up for a hymn - the rise of the melody from the eternal archetypal circle in

\footnotetext{
${ }^{1}$ Greimas's isotopies are semantic elements similar to cells or small parts of the words without meanings and can serve as a basic level of semantic coherence (Tarasti 2002: 75).
} 
"Magic Circle of Sanskrit", the origins of the pagan ritual in "From the Yotvingian Stone" (the hammering of stone), incantation circle of natural phenomena in "Last Pagan Rite". So, the vision of the intersection of the archetype and the metaphor pervades the layer of archaics. The universe of Christianity revives the Baltic selfhood and prophesies its breakthrough - resurrection. The unnamed pagan layer of music enriched with the action of chorale - the metaphor of the resurrection, which already appears as a traditional hymn, chorale or song melody, transfers the meanings to another more fundamental level, where the renewed process of selfhood discovery and identity connections begins. This way, it is possible to define the dramaturgy of archetypes, the transaction of Self and metaphor, the resurrection code, the relationship between levels waiting, tensions, judgment, motion, pulsation, and trajectory formation. The image of archetypal dramaturgy is the glowing darkness where the pulse, the monotony of rhythm, the interaction of low and high layers, and dimensional infinity is essential. The unnamed layer of this metaphoric image is the psychological deepness of a unique Baltic pagan resistance - the Mannerheim Line of eternity, melody, repetitiveness, which surprises with innocent simplicity, fragmentation, and interruptibility but captivates with the internal continuity - the strength of the image of suspended time. "Suspended time" becomes active versus "distorted time". It is the metaphorical code of action of the Baltic states' Mannerheim line, the resistance of the horizontal against the apocalyptic vertical, and its transformation into Enlightenment. The metaphor of this type of music was prevalent through ages until the turn of this century as a metaphor for the "passing times" (JasinskaitèJankauskienè 2008: p. 13).

\section{The metaphor of historicism.}

These metaphor paradigms require real examples from the sources of Baltic music creation. Aivars Kalējs's "Via Dolorosa" (1992), dedicated to victims of the Soviet occupation who did not return from exile in Siberia is one of the most striking and hardly comparable in verses of historicism. Here, the slow syncopated pulse of rhythmic monotony - the unnamed fatalism of heartbeat or rolling railway noise leads the line of the musical image - the metaphor to the analogy of the apocalypse of totalitarianism and the chill of death. However, everything 
remains on the continuation of vision beyond the "threshold" of the metaphor of a musical mark. The metaphor maximises its visual part by absorbing all contexts and centring them on a specific resistive musical repetition of cells like on a Mannerheim Line - an eternal melody. The metaphor factor here coincides with the semantics of musical devices: and the acoustics of hum, rhythm of movement, and other physicalgeometrical parameters, which acquire a visual dimension. In such way, the metaphor changes not only the levels of visualisation but also its linguistic-rhetorical parameter, transforming it into a visual-musical sign of the apocalypse as a symbolic breakthrough gesture of other absolute power (like in Aivars Kalejs "Via Dolorosa").

\section{Metaphor and nature: a cry for freedom. The birds.}

Gradually, nature has acquired a particular significance as a metaphor for freedom in the works of Baltic composers. The environmental cry of music and the significance of the works did not leave any doubt in the 1970-80s. It only strengthened in time: nature and ecology, and, of course, the nation, as well as nature, was calling for help! Nature dies as "the fishes in Daugava die in silence" in the words of Latvian composer Imants Zemzaris. The most striking works emerge where the main character is the nature with its relentless cry for freedom in the works primarily related to the voices of birds like in Algirdas Martinaitis's "Cantus ad Futurum", 1978, Bronius Kutavičius's "Two Birds in the Shade of the Woods", 1974, (based on Rabindranath Tagore's texts comparing the free bird in the woods and the bird in the cage), Pēteris Vasks's "Landscape with Birds" (1980), Pēteris Plakidis "Pastorale", Imants Zemzaris's "Lauks" (Field), 1984, and others.

\section{The metaphor and the vision. Image of the Mannerheim line.}

The texts, which also testify the superiority of the past over the time in the symbolism of historical visions used by composers like Kutavičius (Gaidamavičiūtè 2005: p. 71), draw up a vivid historical imagination. Hereinafter, there are a few examples of metaphorical works of such type: "pagan" oratorios of B. Kutavičius, sonata "Ad Patres", "Musica Serva" by P. Vasks, "Quaternio Latviensis" by L. Apkalnis, "Domine..." by G. Sakalauskas and others. In these works, we observe processes revealing the metaphor of eternal return, or the 
dramaturgy of suspended time, archetypes of the Baltic Selfhood, encompassing all layers of the psychological depth in the consciousness of the historicism. Their problems progressively crystalise into a style of Baltic identity and acquire a specific resistive image of the musical metaphor of the Mannerheim Line. It is an ascetic, fragmented, and fatal rhythmic pulse rising from creeping intonation cells, reminding a rhythm monotony labelled by M. K. Čiurlionis (Čiurlionis 1960: p. 299), able to fill the grim transcendental emptiness of the northern landscape up to the apocalyptic universality and dramaturgical absolute of action. Thus, concerning the Baltic phenomenon, the metaphor of the Mannerheim line "outgrows itself" and becomes a tool of conversion, the concentration of the meaning of action like the somewhat squared metaphor with the mystique of the musical space and the dimension of depth and height. It contains the Enlightenment of the Endarkenment - a shining dark, the meaning of archetypal dramaturgy. Here, the new operational potential of metaphors emerges in a valuable way in terms of musical dramaturgy with the strength to provoke transformation.

\section{Baltic contexts of a metaphor.}

It can be stated that the metaphor fulfils a particular historical mission in Baltic minimalism; its function in dramaturgy decides the changes, renewal, reconstruction, restoration, and reconception. This is particularly important in the "struggle" for the recovery of identity against the disinformation, in the discourse about Selfhood. Here, the function of the metaphor is to disclose the contextuality of history. In Lithuania, there are especially influential literary examples: Marcelijus Martinaitis's “The Ballads of Kukutis", 1977, in which the philosophical paradigm of historical truth suddenly opens up through the literary language of metaphor:

....as Germany burned under Blinstrubiškès Oak they hanged me.

And when they hanged me

I quickly came to my senses

I gave up my land,

the heavens and Lithuania

the heavens and Lithuania. 
Over there, in the beyond, in that other world they gave me an apartment

under Blinstrubiškes oak, they gave me seven feet of meadows

and what more do I need.

M. Martinaitis. The Ballads of Kukutis. The poem "How Kukutis regained his senses". (in Eng.: Martinaitis 2011: p. 33; in Lith.: Martinaitis 1981: p. 147).

Here, the metaphor most accurately names the "theatre" of the Soviet occupation, presented in the form of the unquestionable event of the hanging of the village fool. Such poetry becomes a unique instrument, which awakens not only the linguistic expressionism but the sharp insight of archetypal dramaturgy.

The historical contexts of the Baltic metaphor are uncovered in many angles. Here are the marketplaces (the place of desecration of partisan's bodies), the KGB cellars, the forest bunkers, the borderless horizontal of the sea and the blending of the North with an infinity of time behind the Polar circle for the deportees, spheres of the unknown the other space, suspended time, and transcendental landscapes. These are particular visions filled with harsh historical experiences, which metaphorical energy focuses on the defensive line - continuity, survival, recovery, return, vital impulse - as a rhythmic-intonational cell. Such is the paradigm of the style of this Baltic phenomenon in music. It relies on contexts and their related images, which change into the ornamentation of musical landscapes of eternity. The metaphor as a lexical-style device is transformed into the gesture of musical intonational cell, the eternal melody, the voice of the space of the world in the tune of eternal return.

\section{Metaphor and religion.}

It can be claimed that these two spheres converge at maximum and integrate with each other in Baltic music. Essentially Baltic minimalism becomes a holly canon absorbing the aspects of ringing bells (Arvo Pärt's tintinabuli style), church hymns (Pēteris Vasks's "Musica Serva", "Te Deum"), protestant chorale (Bronius Kutavičius's "Last Pagan Rites") and even the sacral style of pantheistic elements (Bronius Kutvavičius "Pantheistic Oratorio", 1970, "From the Yotvingian Stone", 1983), and can be called the "sacred minimalism". The language of 
Baltic minimalist style is described as fundamentally national and sacramental (Gaidamavičiūtè 2005: p. 133-137).

It can also be argued that in music metaphor takes over the restorative role of the spiritual dimension and religion. It was metaphor's mission during the time when religion was suppressed, socially and ideologically eliminated. The metaphor has become its direct instrument, the factor of moving the image to another dimension, the sign of presence in eternal time, the extraordinary power of transcending the limits. Thus, artistic transformation becomes an interdisciplinary and interspherical function of movement that enables the miracle of the resurrection, the appropriately loaded array of musical devices of the primaeval hum of darkness, misery, striving towards the pulsating light, and its refined illegible subtexts.

The Baltic metaphor of the resurrection also subdues the space and time with its signs, changes the codes of thinking and dimensions of expression. It becomes a philosophical paradigm of sacred canon in the context of new music.

\section{Metaphor and Fluxus.}

Metaphor mainly embodies the following factors of the transformation: a) the breakthrough from the depths, b) the return of the Self, c) the dramaturgical "pilgrim procession", d) the axis of archetype movement between darkness and light, e) the equivalent of a symbol, f) the mystery of space transcendentality, g) hypothetical phenomenon of a vision. It is due to the very active discourse of Baltic historism and its reflection in arts. However, sometimes the metaphor adopts its individual "grand form" of comic aspects like in Fluxus opera "Post Futurum", 2018 (authors: composer G. Sodeika, writer S. Parulskis, director O. Koršunovas, first performed in Lithuanian National Opera and Ballet Theater, Vilnius, February 2018). The grand form of the metaphor - the quasi opera becomes a bizarre metaphoric game of the opera genre, overturning the history, even the music, into different and entirely ironic Fluxus "project" by sacrificing opera and history (like at some degree superficial, historically false comics), politics and music (the pulsating background is more like a tonically charged action space or scenery of historical games) into the renewal of acuity of the 100-year visual sight, which was continuously changing over the time... The 
imagery metaphor in God's Playground. A History of Poland (Davies 1979), i.e. scenography with its abundance of technological and cinematic effects literally determines the effectiveness of this Fluxus epic and converts it into an authentic contemporary creation - a "game between the devil and God" or, as its critics claim, a "game, which is still unfinished". So, a metaphor is elevated into its paradigmatic royal majesty position, enriched with visions changing the time but still open to unexpected fractures and unread contexts. Visions sometimes become oversaturated with comics (the episode about legendary Vytautas the Great). Sometimes, they cross the publicly established red lines as in the favourite postmodernist actions it is customary to hit low-down. Here, the style of total mockery balances on the borderline but, in the end, metaphor saves it all - the reversibility of historical time and how the local issues acquire the game mask. Later, a carnival of metaphors emerges as a vision of famous painting in the House of the Signatories in Vilnius old town - portraits of Signatories of the Act of Independence of Lithuania. The image of historical transformation on stage becomes dominant and sublime, memorable above all other meanings, even above the musical background. However, it is a visual act. The metaphor focuses its dynamism and energy on the image, a scenographic representation that determines the contemporary centre of dramatic tension in the opera. Fluxus uses metaphor as a gaming tool for style transformation and creates a metaphor of history in its sarcastic context.

\section{Intermedial aspects under the influence of metaphor.}

It can be stated that in modern times the metaphor invades other realms where it would not have had a place in pre-modern times. It is a history, which should not be based on a poetic image but the real testimonies. Yet, space exists here for the metaphor too - the dominance of certain aspects of history and its limited image may appear distorted like in the opera "Post Futurum". The metaphor is familiar in its attitudes and bold, even abusive in its relation to religion with mixed images of God and the devil. The metaphor goes far beyond the horizons of literature. It can be brilliantly exploited in politics, shifting the emphasis of the imagination, hybridising the interpretation of reality (Cumming 2007: p. 367-368). Its endless potential lies in the field of disinformation and the emotional dissemination of artistic creation. It may be stated that 
the world becomes metaphoric but also that a metaphor becomes some kind of general image - an intermedial tool of destruction. Its creative phenomenon becomes too playful, theatrically postmodern, and even anti-cultural in terms of postmodern provocation. Many works demonstrate the same trend, not just opera "Post Futurum", yet they retain some historical charm but seemingly asking for purification. It can be argued that the stylistic transformations of postmodernism also carry here a negative effect. Artistic creativity becomes an instrument distorting the convenient wholeness, and the real emptiness of philosophical reflections, which is actually a condition for the death of metaphor, begin to open up. Though the resurrection of the political metaphor also lies in the same medium, in the impossible to ignore political reality only shaken with catastrophic events:

\section{Europe watches the distant}

Wild steppe,

Where the bloody dragonflies flutter.

The Turks moon eyes from the underground.

The Dutch consider and eat their cheese.

V. Landsbergis, Ukrainos golgota [Ukrainian Golgotha] (Landsbergis 2015: p. 223).

\section{The metaphor and also Baroque.}

Moreover, the very metaphor of the passing time in Lithuania became the strengthened Baroque. So, the creators interpret the nation's historical mentality, its multipolar line of survival, incorporating the signs of survival. Here, the fascinating connection to music like the height of the expression of civilisation lies. Modern Lithuanian composers emphasise that Baroque equates to an ideal past, concentration and communication, even some kind of homesickness for the past times (Žiūraitytė 2006: p. 277-278) or structural basis of Vilnius architecture in music with passion for Europe by Algirdas Martinaitis (Gaidamavičiūtè 2005: p. 246-256), as well as reconstruction of historical national identity - the "return home" from the union with Poland (Sabaliauskaite 2016), the reconceptualisation of ethnocentrism to the restoration of statehood within European connections and its "presence in the world" following the idea of return in World is Returning Home. Thoughts of the Eurorealist (Ozolas 2019). It is an 
actual revived factor of Baroque metaphor similar to a tree, which starts to blossom after the Endarkenment age, the returning factor of Enlightenment in the Lithuanian concept of historical identity. However, this phenomenon is named in just one word - Baroque where many unspoken aspects revolve around a unique centre of thought in its entirety, multiplicity, leaving the intellectual imagination to dive into the realms of reconnecting and reintegrating.

The paradigm of metaphor demonstrates its real power once again actualising the transformation of worldview into Baroque as a flawless summary of times.

\section{Conclusions}

Metaphor is an essential factor in the transformation of the new resurrectional power in Baltic music. An essential special Baltic link connects metaphor with archetypes and systematic movements of Self. This approach is based on works of Carl Gustav Jung and his research in the depth of psichology, which works hand in hand with his practice of the physician in psychiatry.

Metaphore is not only a stylistic device of comparisons, poetic images and their transposition but also a demiurge of change of form parameters, the restorer of epoch style and principles of thought. The same can be said about Baltic music. The metaphor here mingles with religion, myth, folkloristic sources of music, literature, the architecture of baroque, and unfolds the path of poetic imagination as an interdisciplinary medium for public communication of meaning.

The main aspects of the metaphor of Baltic music are:

1) relation to nature,

2) relation to the Self / nation / identity / state,

3) relation to history,

4) relation to myth,

5) relation to Baroque,

6) relation to the present - politics and media,

7) relation to the sacred world. Sacrality becomes an aspect of national identity in connection to the other space, another metaphor of salvation.

Here, the metaphor is an instrument of the deepest psychology in music, which shapes the dramaturgy of archetypes and its processes, 
valuable for the return of the Self. It becomes a vital factor for stopping and manoeuvring the casualties of times, helpful for recovering and collecting the experience. Perhaps, the metaphor has become another extraordinary Lithuanian archetype in the sense of self-consciousness for the nation's self-defence.

\section{References}

Čiurlionis, M. K. (1960). Apie muzika ir dailę [About Music and Art]. Edited by V. Čiurlionytè-Karužienè. Vilnius : Vaga, $337 \mathrm{p}$.

Cumming, N. Tapatinimosi siaubai. Reicho Skirtingi traukiniai [The Horrors of Identification: Reich's "Different Trains”]. In: Goštautienè, R. (eds). Muzika kaip kultūros tekstas [Music as Text of Culture]. Vilnius : Apostrofa, 2007, pp. 365-387.

Davies, N. (1979). God's Playground. A History of Poland. New York : Columbia University Press, 638 p.

Gaidamavičiūtè, R. (2005). Nauji lietuviu muzikos keliai [New Roads of Lithuanian Music]. Vilnius : Lietuvos muzikos ir teatro akademija, 407 p.

Jasinskaitė-Jankauskienè, I. (2008). Pasakoja kompozitorius Bronius Kutavičius.

In: Jasinskaitė-Jankauskienè, I. (eds). Broniaus Kutavičiaus muzika. Praeinantis laikas. Vilnius : Versus aureus, pp. 13-35.

Jung, C. G. (2013). Psichologiniai tipai [Psychological Types]. Vilnius : Margi raštai, $623 \mathrm{p}$.

Landsbergis, V. (2015). Ukrainos golgota. 2013-2014 [Ukrainian Golgotha. 20132014]. Vilnius : Tėvynès Sajunga - Lietuvos krikščionys demokratai, 297 p.

Martinaitis, M. (1981). Vainikas [The Wreath]. Vilnius : Vaga, 279 p.

Martinaitis, M. (2011). The Ballads of Kukutis. Todmorden : Arc, 156 p. URL: https://books.google.co.uk/books/about/The_Ballads_of_Kukutis.html?id=Ee TABQAAQBAJ\&printsec $=$ frontcover\&source $=\mathrm{kp} \_$read_button\&redir_esc $=\mathrm{y}$ $\# \mathrm{v}=$ onepage \&q\&f=false (accessed: 29 October 2019).

Ozolas, R. (2019). Pasaulis grižta namo. Euroidealisto mastymai [World is Returning Home. Thoughts of the Eurorealist]. Vilnius : Valstybingumo studijų centras, $261 \mathrm{p}$.

Sabaliauskaite, K. (2016). Silva rerum. Vilnius : Baltos lankos, 286 p.

Stonyte, Ž. (2014). Rethinking Lithuania's Historical and Cultural Past: Two different Perspectives in Poetry and Music. In: Povilionienè, R. and Katinaite, J. (eds). Bronius Kutavičius. Music that changed times. Vilnius : Lithuanian Composers Union, Lithuanian Academy of Music and Theater, pp. 100-109.

Tarasti, E. (2002). Signs of Music. A. Guide to Musical semiotics. Berlin; New York : Mounton de Gruyter, 224 p. https://doi.org/10.1515/9783110899870 Žiūraityte, A. (2006). Skiautinys mano miestui. Vilnius : Lietuvos muzikos ir teatro akademija, $339 \mathrm{p}$. 


\title{
МЕТАФОРА В КОНТЕКСТІ БАЛТІЙСЬКОЇ МУЗИКИ: ІДЕЯ ВІЧНОГО ПОВЕРНЕННЯ
}

\author{
Юрате Ландсберхіте-Бехер \\ orcid.org/0000-0003-2356-7264 \\ jurate128@yahoo.de \\ Литовський інститут культурних досліджень \\ Saltoniškiu g. 58, 08105, Vilnius, Lithuania
}

\begin{abstract}
Анотація. Метафора $є$ основною формою, що надає імпульс феномену балтійської музики. Вона створила новий мовчазний стиль захисту та трансцендентальності, що, врешті-решт, могло б допомогти змінити самосвідомість нації. Мета цієї статті - дослідити лінгвістичну силу метафори, іiі перехід у музику та те, як вона допомогла викрити дезінформацію в період радянського ідеологічного панування. Порівняльна методологія використовується для вивчення метафор у галузі музики, літератури, політології та естетики мистецької філософії. Ця розвідка побудована так, щоб відобразити рух метафори в певні періоди часу. Метафора $є$ потужним інструментом для підвищення значущості архетипів національної ідентичності та прав на державність. Ї̈̈ використання можна порівняти з релігією, природою, сакральністю простору та історії, вона вкрай важлива для засвоєння знань про розвиток нації. Метафора - це оновлений шлях до усвідомлення важливості існування державності та того, що відбувалося в країнах Балтії в часи кардинальних змін. Можна сказати, що метафора допомогла відновити незалежність без армії і надалі продовжує поширювати свій вплив, проникаючи в нові медіа-потоки, пов'язані 3 питанням державності. Висновки статті узагальнюють витоки могутності нації, заснованої на явищі воскресіння архетипів (за теорією К. Г. Юнга), які були знову відкриті за допомогою принципів психології.
\end{abstract}

Ключові слова: Балтія, метафора, історія, простір, ритм, хвилі.

\section{Suggested citation}

Landsbergytė-Becher, J. (2020). Metaphor in the Context of Baltic Music: the Idea of Eternal Return. Pitannâ literaturoznavstva, no. 101, pp. 177-190. http://doi.org/10.31861/pytlit2020.101.177

Стаття надійшла до редакції 15.03 .2020 р. Стаття прийнята до друку 3.07.2020 p. 